2020, Vol. 9, Issue 2

Małgorzata Sieradzka

Associate Professor, Department of Public Business Law, Łazarski University

https://orcid.org/0000-0002-3930-6491

\title{
UNFAIR TERMS IN LOAN AGREEMENTS CONNECTED WITH FOREIGN CURRENCY. COMMENT TO THE JUDGEMENT IN CASE C-186/16 RUXANDRA PAULA ANDRICIUC E.A. CONTRE BANCA ROMÂNEASCĂ SA
}

\begin{abstract}
In the judgment under appeal, the referring court asked the Court in the context of proceedings between a banking institution and several individual borrowers, the interpretation to be given to Article 3(1) and Article 4(2) of Directive 93/13/EEC Council Directive of 5.4.1993 on unfair terms in consumer contracts (OJ L 95, 21.4.1993, p. 29-34). The Court indicated that a term such as that at issue in the main proceedings, incorporated into a loan agreement concluded in a foreign currency between a seller or supplier and a consumer without being individually negotiated, on terms by which the loan must be repaid in the same currency, is covered by the notion of 'main subject matter of the contract' within the meaning of Article 4(2) of Directive 93/13. Furthermore, it is for the national court, upon considering all the circumstances surrounding the conclusion of the contract, to ascertain whether, in the case concerned, all the information likely to have a bearing on the extent of this commitment had been communicated to the consumer, enabling him/her to estimate in particular the total cost of his/her loan. The Court accepted in a judgment that Article 3(1) of Directive 93/13 must be interpreted as meaning that the assessment of the unfairness of a contractual term must be made by
\end{abstract}


reference to the time of conclusion of the contract at issue, taking account all of the circumstances which could have been known to the seller or supplier at that time, and which were such as to affect the future performance of that contract.

Keywords: Directive 93/13, assessment of the unfairness of a contractual term; loan

\section{Facts}

Between 2007 and 2008 the applicants, i.e. Ruxandra Paula Andriciuc and 68 other people (the Applicants), in the main proceedings who, during that period, received their income in Romanian lei (RON), concluded loan agreements with Banca Românească SA (the Bank) denominated in Swiss francs $(\mathrm{CHF})$ with a view to acquiring immovable property, refinancing other credit arrangements or meeting personal needs.

Under Article 1(2) of each of these agreements, the applicants in the main proceedings were required to make monthly payments on the loans in the same currency as that in which they had been concluded, that is in the Swiss franc, with the consequence that the risk of fluctuations requiring an increase in the monthly repayments if the exchange rate of the Romanian lei fell against the Swiss franc was born entirely by the applicants. Furthermore, these agreements contained two clauses, in Article 9(1) and Article 10(3)(9), respectively, that authorized the Bank, once the monthly payments had fallen due or in the event that the borrower failed to comply with the obligations arising from the agreements, to debit the borrower's account and, if necessary, to carry out any conversion of the balance available on the borrower's account into the currency of the contract at the Bank's exchange rate as it stood on the day of that operation. Pursuant to those terms, any difference in the exchange rate was borne entirely by the borrower.

According to the Applicants in the main proceedings, the Bank was in a position to foresee the movement and fluctuations in the exchange rate for the Swiss franc. The exchange risk was not fully explained, since, unlike other foreign currencies used as a reference currency for loans, the Bank did not point out that the Swiss franc fluctuated significantly against the Romanian lei. More generally, the presentation was made in a biased manner, emphasizing the advantages of that type of product 
and the currency used, while failing to point out the potential risks or the likelihood of those risks materializing. In that connection, the applicants in the main proceedings claimed that by failing to inform them in a transparent manner about such fluctuations, the Bank acted in breach of its obligations to inform, warn and advise, and in breach of its duty to draft contractual terms in plain and intelligible language, so as to enable a borrower to understand the obligations arising from the contract which he/she has concluded.

Taking the view that the terms providing for the repayment of the loans in Swiss francs, in so far as they placed the exchange risk on the borrowers, were unfair terms, the applicants in the main proceedings brought an action before the Tribunalul Bihor (District Court, Bihor, Romania) seeking a declaration that those terms were completely invalid, together with an order requiring the Bank to produce, for each loan agreement, a new repayment schedule providing for the conversion of the credit into Romanian lei, at the exchange rate which had been in force when the loan agreements at issue in the main proceedings were concluded. By judgment of 30.4.2015, the Tribunalul Bihor (District Court, Bihor) dismissed the action. That court held that, even though it was not negotiated with the borrowers, the term providing for the repayment of loans in the same currency as that in which the loan agreements had been concluded was not unfair.

The applicants in the main proceedings then brought an appeal against that decision before the referring court. They argued that the significant imbalance between the rights and obligations of the parties was caused by the depreciation of the Romanian lei against the Swiss franc which took place after the conclusion of the agreements, and that the Court has never given a ruling on a question of that nature in its judgments relating to the interpretation of Article 3(1) of Directive $93 / 13^{1}$ on the definition of 'significant imbalance'. The referring court observed that, in the present case, from the moment when the loans at issue in the main proceedings were disbursed, the exchange rate of the Swiss franc had increased considerably and that the applicants in the main proceedings suffered the effects of that increase. Therefore, according to that court, it is important to know whether in accordance with the Bank's duty to inform and advise, it should have informed clients about a possible future increase or decrease

1 Council Directive 93/13/EEC of 5.4.1993 on unfair terms in consumer contracts, OJ L 95, 21.4.1993, p. 29-34. 
in the exchange rate of the Swiss franc at the time of conclusion of the loan agreements, and whether the term at issue in the main proceedings, in order to be regarded as having been drafted in plain intelligible language within the meaning of Article 4(2) of Directive 93/13, was also required to set out all the consequences which might arise which would be likely to affect the price paid by the borrower, such as the exchange risk.

The referring court therefore considered that it is necessary to clarify the interpretation of Article 4(2) of Directive 93/13 that provides for an exception to the mechanism for reviewing the substance of unfair terms laid down under the system of consumer protection put in place by that directive.

In those circumstances, the Cortea d'Appel Oradea (Court of Appeal, Oradea, Romania) decided to stay proceedings and refer the following questions to the Court of Justice of the European Union for a preliminary ruling:

1. Must Article 3(1) of Directive $93 / 13$ be interpreted as meaning that the significant imbalance in the parties' rights and obligations arising from the contract must be evaluated strictly by reference to the time when the contract was concluded or does that imbalance also extend to the case where, during the performance of the contract, whether it is performed at regular intervals or continuously, performance by the consumer has become excessively burdensome in comparison with the time when the contract was concluded because of significant variations in the exchange rate?

2. Must the plainness and intelligibility of a contractual term, within the meaning of Article 4(2) of Directive 93/13, be understood to mean that that term must provide not only for the grounds of its incorporation in the contract and the term's method of operation, or must it also provide for all the possible consequences of the term as a result of which the price paid by the consumer may vary, for example, foreign exchange risk. Moreover, in the light of Directive 93/13, may it be considered that the bank's obligation to inform the customer at the time of disbursement of the loan relates solely to the conditions of credit, namely, the interest, commissions, and guarantees required of the borrower, since such an obligation may not include the possible overvaluation or undervaluation of a foreign currency?

3. Must Article 4(2) of Directive 93/13 be interpreted as meaning that the expressions 'the main subject matter of the contract' 
and 'adequacy of the price and remuneration, on the one hand, as against the services or goods supplied in exchange, on the other' include a term incorporated in a [loan] agreement entered into in a foreign currency concluded between a seller or supplier and a consumer, which has not been negotiated individually, pursuant to which the credit must be repaid in the same currency?'

\section{Court's Position}

The Court of Justice of the European Union (the CJEU) began its considerations from the third question. At first, the CJEU leaned towards the Romanian Government's and the bank's argument that the term at issue in the main proceedings merely reflects the principle of monetary nominalism enshrined in Article 1578 of the Romanian Civil Code, so that, pursuant to Article 1(2) of Directive 93/13, that term does not fall within its scope. According to the CJEU, in that connection, it must be recalled that Article 1(2) of Directive 93/13 introduces an exclusion into the scope of the directive which covers terms which reflect mandatory statutory or regulatory provisions. The CJEU referred to the following judgments: 1) judgment of 10.9.2014, Kušionová, C34/13, paragraph 76, ${ }^{2}$ and 2) judgment of 21.3.2013, RWE Vertrieb, C92/11, paragraph $25^{3}$

The CJEU recalled that it had been already held that exclusion requires two conditions to be met. First, the contractual term must reflect a statutory or regulatory provision and, secondly, that provision must be mandatory. ${ }^{4}$ The CJEU accepted the opinion of the Advocate General that in the subject matter it is for the referring court to assess, having regard to the nature, the general scheme and the stipulations of the loan agreements concerned, as well as the legal and factual context in which these matters are to be viewed, whether the term in question, under which the loan must be repaid in the same currency as that in which it was advanced, reflects statutory

2 Monika Kušionová v SMART Capital, a.s., Case no 34/13, Judgment of 10.9.2014, ECLI:EU:C:2014:2189, para. 76.

3 RWE Vertrieb AG v Verbraucherzentrale Nordrhein-Westfalen eV, Case no 92/11, Judgment of 21.3.2013, ECLI:EU:C:2013:180, para. 25.

4 See Monika Kušionová v SMART Capital, a.s., Case no 34/13, Judgment of 10.9.2014, ECLI:EU:C:2014:2189, para. 78. 
provisions of national law, within the meaning of Article 1(2) of Directive 93/13.

The CJEU emphasized that in carrying out the necessary checks, the national court must take account of the fact that having regard to the purpose of that directive, namely the protection of consumers against unfair terms included in contracts concluded with consumers by sellers or suppliers, the exception provided for in Article 1(2) of the directive is to be strictly construed. ${ }^{5}$ Furthermore, if the referring court were to find that the term at issue in the main proceedings is not covered by that exception, it must then examine whether it falls within the concept of 'main subject matter of the contract' or 'the adequacy of the price and remuneration, on the one hand, as against the services or goods supplied in exchange, on the other', within the meaning of Article 4(2) of Directive 93/13. The CJEU concluded that although it was true that that examination was for the national court alone, it was, however, for the CJEU to elicit from that provision the criteria applicable in that examination.

After analyzing this issue, the CJEU decided that the answer to the third question should be as follows: Article 4(2) of Directive 93/13 must be interpreted as meaning that the concept of 'main subject matter of the contract' within the meaning of that provision, covers a contractual term, such as that at issue in the main proceedings, incorporated into a loan agreement denominated in a foreign currency which was not individually negotiated and according to which the loan must be repaid in the same foreign currency as that in which it was contracted, as that term lays down an essential obligation characterizing that contract. Therefore, that term cannot be regarded as being unfair, provided that it is drafted in plain intelligible language.

Next, the CJEU proceeded to the analysis of the second question. As regards the requirement of transparency of contractual terms, according to the CJEU, as is clear from Article 4(2) of Directive 93/13, the Court has ruled that that requirement, also repeated in Article 5 thereof, cannot be reduced merely to their being formally and grammatically intelligible, but that, to the contrary, since the system of protection introduced by Directive 93/13 is based on the idea that the consumer is in a position of weakness vis-à-vis the seller or supplier, in particular, as regards his/ her level of knowledge, that requirement of plain and intelligible drafting

5 See, to that effect: Monika Kušionová v SMART Capital, a.s., Case no 34/13, Judgment of 10.9.2014, ECLI:EU:C:2014:2189, para. 77. 
of contractual terms and, therefore, the requirement of transparency laid down by the directive must be understood in a broad sense. ${ }^{6}$ Thus, the requirement that a contractual term must be drafted in plain intelligible language is to be understood as also requiring that the contract should set out transparently the specific functioning of the mechanism to which the relevant term relates and the relationship between that mechanism and that provided for by other contractual terms, so that that consumer is in a position to evaluate, on the basis of clear, intelligible criteria, the economic consequences for him/her which derive from it. ${ }^{7}$

The CJEU recalled that the European Systematic Risk Board stated in its Recommendation ESRB/2011/1 of 21.9.2011 on lending in foreign currencies $^{8}$ that financial institutions must provide borrowers with adequate information to enable them to take well-informed and prudent decisions and should at least encompass the impact on instalments of a severe depreciation of the legal tender of the Member State in which a borrower is domiciled and of an increase of the foreign interest rate (Recommendation A - Risk awareness of borrowers, paragraph 1). The CJEU accepted again the observations of the Advocate General that the borrower must be clearly informed of the fact that, in entering into a loan agreement denominated in a foreign currency, he/she is exposing him/herself to a certain foreign exchange risk which will, potentially, be difficult to bear in the event of a fall in the value of the currency in which he/she receives his/her income. Moreover, the seller or supplier, in this case the bank, must be required to set out the possible variations in the exchange rate and the risks inherent in taking out a loan in a foreign currency, particularly where the consumer borrower does not receive his income in that currency. Therefore, it is for the national court to ascertain that the seller or supplier has communicated to the consumers concerned, all the relevant information enabling them to assess the economic consequences of a term, such as that at issue in the main proceedings, on their financial obligations.

6 See, to that effect: Árpád Kásler and Hajnalka Káslerné Rábai v OTP Jelzálogbank Zrt, Case no 26/13, Judgment of 30.4.2014, ECLI:EU:C:2014:282, paras. 71-72; Maria Bucura v SC Bancpost SA, Case no 348/14, Judgment of 9.7.2015, ECLI:EU:C:2015:447, para. 52.

7 See, to that effect: Árpád Kásler and Hajnalka Káslerné Rábai v OTP JelzálogbankZrt, Case no 26/13, Judgment of 30.4.2014, ECLI:EU:C:2014:282, para. 75; Jean-Claude Van Hove v CNP Assurances SA, Case no 96/14, Judgment of 23.4.2015, ECLI:EU:C:2015:262, para. 50.

8 Recommendation of the European Systemic Risk Board of 21.9.2011 on lending in foreign currencies (ESRB/2011/1), OJ C 342, 22.11.2011, p. 1. 
In the light of the foregoing, the answer to the second question was that Article 4(2) of Directive 93/13 must be interpreted as meaning that the requirement that a contractual term must be drafted in plain intelligible language requires, in the case of loan agreements, financial institutions to provide borrowers with sufficient information to enable them to take prudent and well-informed decisions. In light of this connection, that requirement means that a term under which the loan must be repaid in the same foreign currency as that in which it was contracted must be understood by the consumer both at the formal and grammatical level, and also in terms of its actual effects, so that the average consumer, who is reasonably well informed and reasonably observant and circumspect, would be aware both of the possibility of a rise or fall in the value of the foreign currency in which the loan was taken out, and would also be able to assess the potentially significant economic consequences of such a term with regard to his/her financial obligations. It is for the national court to carry out the necessary checks in that regard.

By its first question the referring court asked essentially whether the significant imbalance that an unfair term created between the rights and obligations of the parties arising under the contract within the meaning of Article 3(1) of Directive 93/13 was to be examined only at the time of conclusion of the contract. According to the CJEU, which shared the position of the Advocate General, the unfairness of a contractual term is to be assessed by reference to the time of conclusion of the contract at issue, taking account of all the circumstances which could have been known to the seller or supplier at that time, and which were of such a nature that they could affect the future performance of the contract, since a contractual term may give rise to an imbalance between the parties which only manifests itself during the performance of the contract. The CJEU decided that in order to ascertain whether a term, such as that at issue in the main proceedings, causes a 'significant imbalance' in the parties' rights and obligations arising under the contract to the detriment of the consumer, and contrary to the requirement of good faith, the national court must assess for those purposes whether the entrepreneur, dealing fairly and equitably with the consumer, could reasonably assume that the consumer would have agreed to such a term in individual contract negotiations. ${ }^{9}$

9 See, to that effect: Mohamed Aziz v Caixad'Estalvis de Catalunya, Tarragona i Manresa (Catalunyacaixa), Case no 415/11, Judgment of 14.3.2013, ECLI:EU:C:2013:164, paras. 68-69. 
Upon consideration of the foregoing, the answer to the first question should be as follows: Article 3(1) of Directive 93/13 must be interpreted as meaning that the assessment of the unfairness of a contractual term must be made by reference to the time of conclusion of the contract at issue, taking account all of the circumstances which could have been known to the seller or supplier at that time, and which were such as to affect the future performance of that contract. It is for the referring court to assess, having regard to all of the circumstances of the case in the main proceedings, and taking account, in particular, of the expertise and knowledge of the seller or supplier (in the present case the bank), with regard to the possible variations in the exchange rate and the risks inherent in taking out a loan in a foreign currency, of the existence of a possible imbalance within the meaning of that provision.

\section{Commentary - the impact of the judgment on Polish law}

The judgement in question has a great impact on the situation of Polish consumers because, similar to the Romanian case, many Poles took loans in Swiss francs during a similar period of time. For many years (even up to today), we have been witnessing intense public debate concerning this problem, i.e. one unexpected for many consumers with regard to the scale of change in the exchange rate of Swiss franc and thus the level of their indebtedness to various banks. It is obvious that these consumers were a weaker party in the loan agreements in question. Indeed, some people even say that banks as professionals had some influence upon the fluctuation of the Swiss franc exchange rate.

To determine the impact of the judgment of the CJEU of 20.9.2017 on Polish law, it is necessary to present the position of the CJEU expressed in this judgment. Firstly, the CJEU considered that a contractual term incorporated into a loan agreement denominated in a foreign currency, which was not individually negotiated and according to which the loan must be repaid in the same foreign currency falls within the concept of 'main subject matter of the contract'. ${ }^{10}$ Therefore, that term cannot be regarded

10 The 'main subject matter of the contract' should be considered to be those terms and conditions of the contract that define its essential services and which, therefore, characterise the contract. However, these conditions, which are accessory to the conditions deciding the very essence of the contractual relationship, are not covered by this notion. 
as being unfair, provided that it is drafted in plain intelligible language. However, it was pointed out that this position cannot be reduced merely to its being formally and grammatically intelligible, because the system of protection introduced by Directive 93/13 is based on the idea that the consumer is in a position of weakness vis-à-vis the seller or supplier, in particular as regards his/her level of knowledge. The loan agreement should, hence, set out transparently the specific functioning of the mechanism to which the relevant term relates and the relationship between that mechanism and that provided for by other contractual terms, so that that consumer is in a position to evaluate, on the basis of clear, intelligible criteria, the economic consequences for him/her which derive from it. ${ }^{11}$

In regard to the above, it should be also pointed out that the financial institutions must provide borrowers with adequate information about the risk connected with the loans denominated in a foreign currency. The provided information should be sufficient to enable them to take prudent and well-informed decisions and should at least encompass the impact on instalments of a severe depreciation of the legal tender of the Member State in which a borrower is domiciled and of an increase of the foreign interest rate.

The evaluation in this respect, was to be conducted by the national court in the light of all the relevant facts, including the promotional material and information provided by the lender in the negotiation of the loan agreement, and considering that the average consumer is reasonably well informed and reasonably observant and circumspect. ${ }^{12}$

Finally, the CJEU considered that the unfairness of a contractual term should be assessed by reference to the time of conclusion of the contract at issue, taking account of all the circumstances which could have been known to the seller or supplier at that time, and which were of such a nature that they could affect the future performance of the contract, since a contractual term may give rise to an imbalance between the parties

See A. Jabłońska, M. Namysłowska, Nowyład dla konsumentów? O planowanych zmianach prawa konsumenckiego $w$ Unii Europejskiej [A new deal for consumers? About planned changes in consumer law in the European Union], 'Europejski Przegląd Sądowy' 2018, no 10.

11 Árpád Kásler and Hajnalka Káslerné Rábai v OTP Jelzálogbank Zrt, Case no 26/13, Judgment of 30.4.2014, ECLI:EU:C:2014:282, para. 75; Jean-Claude Van Hove v CNP Assurances SA, Case no 96/14, Judgment of 23.4.2015, ECLI:EU:C:2015:262, para. 50.

12 See Bogdan Matei and Ioana Ofelia Matei v SC Volksbank România SA, Case no 143/13, Judgment of 26.2.2015, ECLI:EU:C:2015:127, para. 75. 
which only manifests itself during the performance of the contract. Herein, the evaluation of the national court should not be limited to the formal and grammatical aspect of this condition. The assessment, having regard to all of the circumstances of the case in the main proceedings, should take account, in particular, the expertise and knowledge of the seller or supplier - in the present case, the bank, as far as concerns the possible variations in the rate of exchange and the inherent risks in contracting a loan in a foreign currency. The subject matter of the assessment should also be the issue of whether there was a potential imbalance within the meaning of Article 3(1) of Directive 93/13/EEC, wherein eventually the bank failed to comply with the requirement of good faith.

It follows from the above that the inequality between a consumer and a seller or supplier should be levelled by interference of a third party that is the court. Furthermore, the national court should examine of its own motion whether the terms of an agreement are unfair and eventually eliminate the lack of balance between a seller or supplier and a consumer. If the national court concludes that the contractual term is unfair, it may confine itself to a declaration of invalidity, without the possibility of changing the term's content and replacing it with a provision of national law of the dispositive nature.

Therefore, two situations may occur. In the first case, a contract without this condition may continue to be in force between the parties. In the second situation, the nullification of the term entails the necessity of invalidating the whole agreement. It should be emphasised that the invalidation of whole agreement may lead to severe consequences for a consumer and as the CJEU stated, a situation from which the consumer should be protected. On a side note, both the invalidation of a contract and elimination of unfair contractual term will have an ex tunc effect. At this point, it should be noted that the purpose of the Directive 93/13/EEC is not to eliminate all contracts with unfair terms from the market, but to restore the balance between parties while, in principle, upholding it as a whole.

In conclusion, it should be considered that the CJEU adopted a proconsumer interpretation of the provisions of the EU law, ruling that an intelligible statement that loan is linked to a foreign currency does not determine the fairness of the contractual terms. In the light of the position presented by the CJEU - the national courts of member European Union states should examine all of the circumstances, in particular, the method of presentation of the contractual conditions to a consumer - not only in the context of standard declarations signed by the borrower on the forms created by the banks, but also in the light of advertisements and promotion 
aimed at disseminating a given financial product. It should also be assessed whether the borrowers were reasonably well-informed about exchange risk and this should not be limited just to information about the existence of such phenomenon, but also about its scale, and even whether they were provided with the prognosis of exchange rate fluctuations prior to the signing of the contract. ${ }^{13}$

Transferring the above considerations to the Polish practice of jurisprudence, it should be pointed out that the provisions of the Directive 93/13/EEC will apply to loans granted and repaid in a foreign currency. However, Article 69(2)(4a) of Banking law ${ }^{14}$ is not a provision mentioned in Article 1(2) of Directive 93/13/EEC because it cannot be directly reflected in the content of a contract with the consumer. The disposition of the provision in question contains only the obligation to include the relevant provision in the loan agreement which unequivocally sets out the principles of currency conversion, not determining the content of such provision. Taking into account the above, the provisions of contracts cannot be considered as reflecting legislation and regulations to which the Directive 93/12/EEC does not apply. ${ }^{15}$

The commented judgment of the CJEU indisputably fortifies consumer protection, whereby the national courts were granted a particular role to decide the fate of loan agreements connected with foreign currency while taking into consideration the circumstances of the individual case. As the CJEU concluded, these agreements, in principle, are admissible. Moreover, the national courts should not lose sight of the fact that the consumer is a weaker party of the contractual relationship, therefore,

13 M. Matusiak-Frącczak, Polska praktyka orzecznicza w sprawie kredytów powiązanych z walutą obca a wyrok Trybunału Sprawiedliwości z 20.9.2017 r., C-186/16, Ruxandra Paula Andriciuc i inni przeciwko Banca Românească SA [Polish case law practice on loans linked to foreign currency and judgment of the Court of Justice of 20.9.2017, C-186/16, Ruxandra Paula Andriciuc and others v Banca Românească SA], 'Europejski Przegląd Sądowy' 2018, no. 4, at p. 44; W. Gontarski, Nieuczciwe warunki w umowach konsumenckich o kredyt w walucie obcej. Glosa do wyroku TS z dnia 20 września 2017 r., C-186/16 [Unfair terms and conditions in consumer contracts for foreign currency credit. Glossary to the ECJ Judgment of 20 September 2017, C-186/16], LEX/el. 2017.

14 Polish OJ 1997, no. 140, item 939.

15 J. Długopolski, Ryzyko kursowe przy indeksacji kredytu konsumenckiego kursem obcej waluty [Foreign exchange risk in consumer credit indexation with a foreign currency rate], [in:] P. Kostański, P. Podrecki, T. Targosz (eds.), 'Experientia docet. Księga jubileuszowa ofiarowana Pani Profesor Elżbiecie Traple' [Experientia docet. Liber Amicorum in honour of Professor Elżbieta Traple], Warszawa 2017, p. 1343-1347. 
the bank will have to comply with the specific duty of providing all relevant information.

It is pointed out in literature that the general declaration of awareness of exchange rate risk may be insufficient to agree with a bank in a dispute with a consumer, if the method of presentation of a loan, especially its promotion, could introduce an imbalance between parties and influence the consumer's assessment of long-term effects of the contract, and even that the pressure to sell loans denominated in a Swiss francs at the time when the currency reached the historical minimum exchange rate resulted in the conscious exposition of borrowers to losses caused by the rate's aspiration to reach a multi-year average level of valuation over the duration of the loan period. ${ }^{16}$ Furthermore, when assessing foreign currency loan agreements, the court should not forget the way in which it makes it necessary to consider whether banks have actually exercised due diligence in informing consumers about the risks associated with such loans, in particular, whether the conditions of good faith, balance and transparency were met. ${ }^{17}$

The analysis of the existing case-law leads to the conclusion that courts hearing a case on loan agreements denominated in foreign currency were focused on determining whether the agreement or its individual provisions complied with the provisions of the Act, in particular, Article 69 of the Banking Law, overlooking the level of the consumer's knowledge about the actual risk associated with signing a loan agreement denominated in foreign currency. The uncritical assumption that any change in exchange rate is a well-known fact and that the consumer should be aware of it is also incorrect. Directive 93/13/EEC was based on the conviction that the consumer was the weaker party to the contractual relationship, both in terms of negotiating power and in terms of the degree of given information, and that he/she therefore accepted the terms of the contract as previously drafted by the seller or supplier, without having any influence on their content.

In the case of loan agreements denominated in foreign currency, the consumer acted in the confidence that the bank offered the loan as a financial instrument relatively safe for consumers. Furthermore, the banks had the specific obligations to look after the long-term interests of consumers, which should be reflected in a duty to provide accurate information at every stage of the loan procedure.

16 M. Matusiak-Frącczak, supra note 13, p. 44.

17 Árpád Kásler and Hajnalka Káslerné Rábai v OTP Jelzálogbank Zrt, Case no 26/13, Judgment of 30.4.2014, ECLI:EU:C:2014:282, para. 40. 
The position set out by the CJEU requires national courts to examine whether the bank has complied with this obligation. However, the CJEU did not address the effects of recognising a term of a loan agreement as unfair, and the existing case-law of Polish courts does not allow an unambiguous conclusion in this respect.

The consequence of invalidity should be applied with extreme caution, taking due account of the interests of the consumer. A declaration of the invalidity of the agreement relates to an obligation of a reciprocal reimbursement on both parties to the agreement, and this raises many practical problems, including the need for a one-off reimbursement of a significant amount of money by the consumer. Nevertheless, an analysis of the case law of common courts leads to the conclusion that sometimes a declaration of invalidity of a loan agreement and an obligation for the parties for reciprocal settlement of accounts may benefit the consumer. This is because the consumer is obliged to reimburse the bank for the amount paid nominally in Polish zlotys, without taking into account any changes in exchange rates that occurred after the date of signing the contract, since, in the opinion of the courts, the assessment of the legality of the contract cannot take into account the factor of economic impact on the parties of concern. In the author's opinion, a solution acceptable to both the consumer and the bank would be a declaration of invalidity of the part of the legal act covering the terms questioned by the consumer, and not the entire loan agreement.

\section{Bibliography}

1. Długopolski J., Ryzyko kursowe przy indeksacji kredytu konsumenckiego kursem obcej waluty, [in:] Kostański P., Podrecki P., Targosz T. (eds.), 'Experientia docet. Księga jubileuszowa ofiarowana Pani Profesor Elżbiecie Traple’, Warszawa 2017

2. Gontarski W., Nieuczciwe warunki $w$ umowach konsumenckich o kredyt w walucie obcej. Glosa do wyroku TS z dnia 20 września 2017 r., C-186/16, LEX/el. 2017

3. Jabłońska A., Namysłowska M., Nowy ład dla konsumentów? O planowanych zmianach prawa konsumenckiego w Unii Europejskiej, 'Europejski Przegląd Sądowy' 2018, no. 10

4. $\quad$ Matusiak-Frącczak M., Polska praktyka orzecznicza w sprawie kredytów powiqzzanych z waluta obcq a wyrok Trybunatu Sprawiedliwości z 20.9.2017 r., C-186/16, Ruxandra Paula Andriciuc i inni przeciwko Banca Românească SA, 'Europejski Przegląd Sądowy' 2018, no. 4 